Crop Breeding and Applied Biotechnology 14: 54-60 2014

Brazilian Society of Plant Breeding. Printed in Brazil

REVIEW

\title{
Plant breeding with marker-assisted selection in Brazil
}

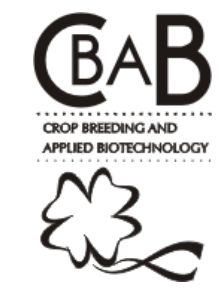

Ney Sussumu Sakiyama ${ }^{1 *}$, Helaine Christine Cancela Ramos ${ }^{2}$, Eveline Teixeira Caixeta ${ }^{3}$ and Messias Gonzaga Pereira ${ }^{2}$

Received 03 June 2013

Accepted 03 December 2013

\begin{abstract}
Over the past three decades, molecular marker studies reached extraordinary advances, especially for sequencing and bioinformatics techniques. Marker-assisted selection became part of the breeding program routines of important seed companies, in order to accelerate and optimize the cultivar developing processes. Private seed companies increasingly use marker-assisted selection, especially for the species of great importance to the seed market, e.g. corn, soybean, cotton, and sunflower. In the Brazilian public institutions few breeding programs use it efficiently. The possible reasons are: lack of know-how, lack of appropriate laboratories, few validated markers, high cost, and lack of urgency in obtaining cultivars. In this article we analyze the use and the constraints of marker-assisted selection in plant breeding programs of Brazilian public institutes.
\end{abstract}

Key words: Molecular markers, indirect selection, MAS.

\section{INTRODUCTION}

The possibility of using molecular markers in plant breeding was presented in the 80 's by Beckmann and Soller (1986) and Paterson et al. (1988). The progress of such application in plant breeding was reviewed by Collard and Mackill (2008), Xu and Crouch (2008), Hospital (2009), and Shuster (2011). The advantage of molecular markers over phenotypic data is the possibility to compare genotypes, even if they are sampled in different environment, type of tissue or stage of development. Another advantage is the theoretical possibility to detect DNA polymorphisms through the entire genome.

The number of scientific publications on marker-assisted selection (MAS) and quantitative trait loci (QTL) $(2,000$ and 5,000 papers year ${ }^{-1}$, respectively) demonstrated the high interest of the scientific community on molecular markers, although their reliability as selection criteria was still questionable in many cases (Schuster 2011). In fact, previous review had already indicated the need of improving sampling, genotyping, and analysis techniques, in order to identify reliable markers for plant breeding purposes $(\mathrm{Xu}$ and Crouch 2008).

These improvements are coming continuously and very fast. Important scientific advances on molecular markers have occurred, especially for DNA sequencing and bioinformatics techniques, which allowed, for instance, the development of expressed sequence tag based microsatellites (EST-based microsatellites) and single nucleotide polymorphisms (SNPs).

A microssatellite is a single pair or a small sequence of base pairs repeated in tandem. The polymorphism for a microsatellite is the variation of the number of tandem repeats in a specific locus of a population. EST-based microsatellites markers are based on ESTs that are present in sequenced portions of cDNA. Strong association between genotype and phenotype can be identified with these markers, which is usefull in plant breeding (Ma et al. 2010, Mulato et al. 2010, Mishra et al. 2012, Yamini et al. 2013).

A SNP is based on single nucleotide variation possibility in a specific point of DNA. The high frequency of such variation through the genome and the feasibility of its detection by DNA sequencing techniques allow the identification of enormous number of SNPs, both for intragenic and intergenic regions of the genome. Therefore, SNP markers are increasingly used for genetic linkage maps and QTL analysis, at relatively low cost (Shirasawa et al. 2010, Fu-Hao et al. 2012, Ye et al. 2012, Zou et al. 2013).

With the next-generation sequencing (NGS), it is now possible to analyse thousands of markers across the entire genome. It enables comprehensive genome-wide association studies, even in populations with little or any previous

\footnotetext{
${ }^{1}$ Universidade Federal de Viçosa (UFV), Departamento de Fitotecnia, 36.571-000, Viçosa, MG, Brazil. *E-mail: sakiyama@ufv.br

${ }^{2}$ Universidade Estadual do Norte Fluminense Darcy Ribeiro (UENF), Laboratório de Melhoramento Genético Vegetal, 28.013-602, Campos dos Goytacazes, RJ, Brazil

${ }^{3}$ Embrapa Café, 70.770-901, Brasília, DF, Brazil
} 
genetic information. Genome-wide selection or genomic selection (GS) has been proposed as a new promising form of MAS (McCouch et al. 2010, Davey et al. 2011, Garcia et al. 2011, Grattapaglia and Resende 2011, Fritsche-Neto et al. 2012, Oliveira et al. 2012). GS is based on molecular markers that are in linkage disequilibrium with QTLs, for example. These molecular markers are selected from a large number of markers distributed throughout the whole genome of a given population without the need of structured segregating population or linkage map.

In this article we analyze the use and the constraints of marker-assisted selection in plant breeding programs of Brazilian public institutes.

\section{MOLECULAR MARKERS IN PLANT BREEDING}

Molecular markers can be used in many steps of a plant breeding program, e.g. germplasm characterization, pedigree and evolution studies, parental selection for crossing, test for $F_{1}$ hybrid confirmation, test for genetic purity of seeds, cultivar protection, breeding strategies establishment, linkage map construction, and mapping of genes and QTLs associated with biological processes.

Marker-assisted selection (MAS) is the indirect selection of a trait of interest based on genetically associated molecular markers (usually DNA markers). MAS may be indicated in the following situations: the direct phenotypic selection is more expensive or time-consuming; the expression of the gene(s) requires specific biological or environmental conditions that are absent or avoided; the heritability $\left(h^{2}\right)$ of the trait is low and the phenotypic selection is consequently less efficient; and multiple traits or several genes (or QTL) for the same trait are simultaneously or cumulatively under selection (pyramiding).

The new paradigm of MAS in plant breeding came up when the seed companies started producing transgenic cultivars. Backcross marker assisted method has been used to fix a transgene within the cultivar (Micallef et al. 1995, Moose and Mumm 2008, Liu et al. 2010, Roy et al. 2011, Roy et al. 2012). In each backcross generation, molecular marker(s) linked to the transgene (the transgene itself or its fragment can be the marker) are used to select transgenic individuals, while other polymorphic markers of recurrent and donor parents are used to remove the linkage drag and recover the recurrent genome. MAS can be used in any breeding method (e.g. backcross marker assisted method) for any single gene transfer procedure if reliable markers exist and the indirect selection is more advantageous than the direct selection of the trait.

Backcross marker-assisted method has been used to introgress favorable alleles at quantitative trait loci in rice (Siangliw et al. 2007, Iftekharuddaula et al. 2011, Cuc et al. 2012), corn (Bouchez et al. 2002), and common bean (Miklas 2007). Most important agronomic traits are usually under quantitative genetic control, exhibiting low to moderate heritability $\left(h^{2}\right)$. For selection of such traits, well estabilished field experimental strategies and statistical analysis have been successfuly used to overcome part of the environment effects. Additionaly, molecular markers can be statistically associated with quantitative traits loci (QTL) and used to increase the genetic gain. The contribution of QTLs to increase genetic gain depends on the magnitude of QTL effects, precise estimation of the positions, and stability across multiple environments and across relevant breeding germplam (Moose and Mumm 2008).

Marker-assisted selection is used in the routine of important breeding programs, as it is shown below:

\section{Pioneer}

"The Accelerated Yield Technology (AYT a key part of a comprehensive plant accelerate yield gain and broaden resistance to key diseases and insects by novel trait integration through our proprietary gene mapping, molecular breeding technologies and field testing protocols.

Pioneer has led the way in developing proprietary marker-assisted selection processes, most not ably to protect soybean yield from harmful pests such as soybean cystnematode, Phytophthora root rot, brown stem rot, sudden death syndrome and frogeye leaf spot.

In addition to employing molecular breeding technologies to protect yield, AYT marker technologies are now being used to boost the genetic yield potential of Y Series soybeans as well.

The AYT process starts with Pioneer researchers mining and analyzing their vast germplasm data base to identify native genes associated with high yields.

Using molecular markers and patented molecular breeding techniques, plants cientists are able to track and select native genes associated with increased yields and stack these genes in elite Pioneer varietal lines.

These break throughs, using non-transgenic biotechnologies, allow Pioneer researchers to quickly and efficiently "design" varieties carrying these yield-enhancing genes. (https://www.pioneer.com/home/site/us/products/soybean/ seed-traits-technologies-soybeans/ayt-system/).

\section{Monsanto}

In the past, this work (plant breeding) was done in greenhouses and fields, and could be very time-consuming. 
But with today's technologies our plant breeders can see the DNA and genetics of plants and make more informed decisions earlier in the breeding process. By the time they getin to field research trials, they have already pre-screened and eliminated the least powerfull breeding stock.

Our Competitive Advantage: Monsanto can continuously deliver unique combinations of new traits and genetics through a combination of seed chipping and molecular breeding. What is remark able about this process is we can analyze each seed before planting and only plant the seeds with product potential greatly improving the efficiency of the breeding process and the quality of the plants.

Molecular Breeding: Molecular breeding, in practice, creates an inventory of a plant's genes and what those genes do. Once the DNA to those genes are identified (known as markers), our scientists can use those markers to tell which plants we want to use to breed the next generation of high-performing plants. It's like going from using a compass to a GPS system, tremendously cutting down on time and resources.

Seed Chipping: Our seed chippers, designed by Monsanto engineers, allow us to determine the genetics of a seed without destroying the seed itself. The chipper sorts and rotates a seed so a tiny tissue sample can be shaved off to be analyzed. If that seed contains the genetic traits we desire, the seed is still viable, so a breeder can plant it in a field test and use it in the breeding process to create more seeds of its kind.

Using technologies and scientific knowledge of today and applying it to the age-old practice of breeding allows us to find the best-of-the-best germplasm, or genetics, and get high-performing seeds to farmers' fields faster. Compared to conventional breeding, our breeding program today is doubling the rate of improvement in key genetic characteristics such as yield and important agronomic traits, which can help agriculture be more sustainable. (http://www. monsanto.com/products/Pages/breeding.aspx).

\section{Dow Seeds}

The breeding techniques employed by Dow encompass the entire range from conventional breeding, through to advanced DNA analyses.

For conventional breeding, the company has the advantage of being able to procure genetic material world-wide, and to be in possession of one of the world's best reserves of parental lines and hybrids. Before release, the hybrids developed from the company's breeding programs are tested over several years in Dow's highly developed worldwide network of yield and disease resistance trials.
The company also has the full range of facilities available for screening progenies for oil percentage and oil composition, plus highly developed laboratory techniques for DNA analysis. One important consequence of having extensive DNA laboratory facilities is that genetic markers have been, and are being, developed for all important traits in sunflower breeding, particularly those associated with disease resistance. This enables resistant hybrids to be developed and commercialized much more rapidly than would otherwise be the case. (http://www.dowseeds.eu/ breeding/sunflower.htm).

\section{Coodetec}

Coodetec (Cooperativa Central de Pesquisa Agrícola), a Brazilian technological based company owned by the members of 32 farmers cooperatives, uses microssatellites for germplasm characterization, diversity analysis of heterotic groups, parental selection for crossing, $\mathrm{F}_{1}$ hybrid confirmation, mapping of genes and QTLs, tests for genetic purity of seeds, cultivar protection, and marker-assisted selection.

With backcross marker-assisted selection Coodetec produced transgenic cultivars of soybean (CD 237RR, CD 250RR, CD 206RR, CD 202RR, CD 215RR, CD 221RR, CD 224RR, CD 228RR) and corn (CD 316Hx, CD 393Hx). Marker-assisted selection is been used to fix the event crylAc within soybean cultivar Intacta RR2 Pro and to eliminate the RR1 event from Intacta RR2. It is also been used for indirect selection of cyst nematode resistant individuals in soybean segregating populations. With the introduction of SNPs it is expected that several traits will be improved by indirect selection (Ivan Schuster, Coodetec, personal communication).

\section{Embrapa Maize \& Sorghum}

Microsatellites and SNPs are used in Embrapa breeding program of maize and sorghum for diversity analysis, elite lines genotyping, cultivar protection, marker-assisted selection, and prospecting genes and QTLs associated with aluminium (Al) tolerance, prhosphorus (P) use efficiency, and disease resistance.

A rare allele of the gene SbMATE associated with aluminium (Al) tolerance in sorghum was introgressed within elite lines by backcross marker-assisted method. In corn, a rare QTL with major effect for Al tolerance was identified and is being introgressed within elite lines, with promising results. It is an important breeding goal to deliver Al tolerant cultivars of sorghum and corn, as the Al toxicity is one of the major constraints for crop production in Brazil (Claudia Teixeira Guimarães, Embrapa Milho \& Sorgo, personal communication). 


\section{CONSTRAINTS OF MOLECULAR MARKERS IN PLANT BREEDING}

The increasingly use of marker-assisted selection (MAS) in plant breeding programs is strategicaly important, especially for crops of great importance in the seed market, such as corn, soybean, sunflower, and cotton, which large companies compete for. However, the impact of marker-assisted selection in plant breeding is still below the theoretical possibilities. The reasons were pointed by Collard and Mackill (2008): the impact may not be published for confidenciality or other reason; the DNA marker technology is still recent, the genes and QTLs mappings are not sufficiently reliable and accurate for indirect selection use, the polymorphic markers are limited in breeding material, the mapping population background is different from the population under selection, the QTL $x$ environment interaction effect was not measured, the high cost of MAS, there is an application gap between molecular and breeding researches, and there is a knowledge gap among molecular biologists and plant breeders. Such difficulties are even more important in public institutions, especially in developing countries. Additional difficulties were reported by Ruane and Sonnino (2007), Collard and Mackill (2008), Moose and Mumm (2008), Gupta et al. (2010), Ribaut et al. (2010) and Delannay et al. (2012). We present below a reflection on the situation in Brazil.

In Brazil, private seed companies might follow the international tendency of increasing the use of MAS, since they are competing for one of the largest seed market in the world. In public institutions, however, most breeders do not use and do not plan do use MAS in their breeding programs.

The following reasons may explain the unconcern or difficult to use MAS in Brazilian public breeding programs: lack of know-how, lack of appropriate laboratories, few validated markers, high cost, and lack of urgency in obtaining cultivars.

\section{Lack of know-how}

Most Brazilian breeders that are in charge of breeding programs in public institutions have a strong background in conventional breeding, but little knowledge or experience in molecular markers and bioinformatics. As these two areas are very complex and are continuously in evolution, it becomes difficult for them to introduce the marker-assisted selection in their programs. In the other side, molecular markers and bioinformatics specialists often have little or any research experience with conventional breeding procedures and they may not be able to do the breeders field experimental job.

The interaction of a multidisciplinary qualified teamwork could be a good alternative. This is how good private compa- nies are organized and work. However, the multidisciplinary teamworks in public institutions may not even exist. If they do, the interaction may not be easy, so the professionals goals are frequently very different. It can be observed that the presence of a group of professionals with different skills does not necessarily form a teamwork.

\section{Lack of appropriate laboratories}

A breeder in charge of a public breeding program rarely have a good molecular marker laboratory available for a routine screening of large number of plants. Plant molecular laboratories in Brazilian public universities are conducted by research groups that have no focus on cultivars development.

Partnership could be a good alternative, despite the difficulties described above. Another promising alternative is the paid service offered by private specialized laboratories for molecular screening of high number of plants.

\section{Few validated markers}

The use of marker-assisted selection is recommended after the identification of markers that are relevant and reliable. Molecular markers are relevant if facilitate, improve, or accelerate the process of plant trait selection. They are reliable if consistently produce the expected results in the process of indirect selection.

The identification of relevant and reliable markers for given species depends on: choosing important traits to be improved, choosing appropriated populations and/or genetic design, and precise phenotyping and genotyping. These prerequisites may not be observed and the validation of the marker fails. Then, for many species, relevant and reliable markers associated with traits to be improved are still scarce or inexist. For many cultivated species, molecular aspects investigations are still in the initial phase, or have not yet started. As the molecular-assisted selection succeed in breeding soybean, corn and other important crops breeding, the interest in other species will grow.

\section{High cost}

The cost of marker-assisted selection is still high due to the investments that are required in terms of human resources, equipments, and chemical reagents. In the other hand, the use of MAS in plant breeding is determined by its potential benefits. However, the contribution of MAS to significatively increase the efficiency of a public breeding program is uncertain for many species. Therefore, the use of MAS may not be good in terms of cost-benefit ratio.

For example, if high genetic gains for agronomic traits of a given species are easily achieved though conventional breeding methods, MAS may not be essencial for this species, 
unless specific need comes up. It seams to be the situation for many species that are in the initial phase of genetics and breeding studies and, therefore, the genetic potential can be well explored without the need of MAS.

The use of small number of crosses and small segregant populations are also common in public breeding programs. Then, the advantage of using MAS to reduce phenotyping labor remains only for special situations in which it is difficult or expensive.

\section{Lack of urgency}

The competition for the seed market estimulated the large private companies to optimize the efficiency of their breeding programs. They improved field experiments, laboratory tests, statiscal analysis, planning processes, and decision making steps. Their goal is to obtain a new superior cultivar in the shortest possible time. The release of a new cultivar is always urgent, as it may be the key for its adoption by the farmers in the next crop season. In this context, marker-assisted selection is used because it accelerates the breeding process.

Release a new cultivar is not always an urgent goal in the public institutions, especially in universities, in which breeders may have other priorities, such as teaching and publishing (interestingly, publishing a good paper about a cultivar is academically more valued than the cultivar itself and its impact on the agriculture). The lack of urgency in releasing new cultivars may become breeding programs obsolete and inefficient compared to private programs. Nevertheless, public breeding programs will continue to be indispensable (but not necessarily urgent) for many crops.

\section{FINAL CONSIDERATIONS}

The Brazilian public breeding programs are facing the transition to the new technological wave of plant breeding: the marker-assisted selection. The constraints described above will be overcome if new public cultivars remain relevant to the national agriculture.

"Molecular" and "conventional" breedings are the same old and good plant breeding in constant evolution. Classic breeding methods are efficient to produce improved cultivars. Marker-assisted selection increases the efficiency of the methods. The colaboration, rather than competition, will prepare a breeding team to face the biotic and abiotic adversities and the challenges of supplying the society with food, fibres, and bioenergy.

Adequate genotyping and phenotyping are both important for the success of plant breeding with marker-assisted selection. There are reasons to be optimistic about genotyping. Large scale genotyping is becoming faster, cheaper and more automatic. Then, the increasing use of marker-assisted selection in plant breeding is inevitable. With the fast and constant advance of molecular technologies, it is plausible to predict that the main constraint in the near future will be the ability of the breeder to make a high quality phetotyping. It will require well trained breeders.

\section{ACKNOWLEDGMENT}

The authors would like to thank CNPq for the research scholarships and to Dr. Ivan Schuster from COODETEC and Dr. Claudia Teixeira Guimarães from Embrapa Maize \& Sorghum for the breeding programs informations.

\section{Melhoramento de plantas com seleção assistida por marcadores no Brasil}

Resumo - Ao longo das três últimas décadas os estudos sobre os marcadores moleculares alcançaram avanços extraordinários, em especial nas técnicas de sequenciamento e bioinformática. A seleção assistida por marcadores tornou-se parte da rotina dos programas de melhoramento de importantes empresas de sementes, com o objetivo de acelerar e otimizar o processo de desenvolvimento de novas cultivares. Empresas privadas de sementes crescentemente adotam a seleção assistida por marcadores, especialmente para as espécies de grande importância para o mercado de sementes, como milho, soja e girassol. Nas instituições públicas brasileiras poucos programas de melhoramento a adotam eficientemente. As possíveis razões são: falta de "know-how", falta de laboratório adequado, poucos marcadores validados, alto custo e falta de urgência na obtenção de cultivares. Neste artigo são analisados o uso e as limitações da seleção assistida por marcadores nos programas de melhoramento de plantas dos institutos públicos brasileiros.

Palavras-chave: Marcadores moleculares, seleção indireta, MAS.

\section{REFERENCES}

Beckmann JS and Soller M (1986) Restriction fragment length polymorphisms and genetic improvement of agricultural species. Euphytica 35: 111-124.

Bouchez A, Hospital F, Causse M, Gallais A and Charcosset A (2002) Marker-assisted introgression of favorable alleles at quantitative trait loci between maize elite lines. Genetics 162: 1945-1959.

Collard BC and Mackill DJ (2008) Marker-assisted selection: an approach for precision plant breeding in the twenty-first century. Philosophical Transactions of the Royal Society of London 363: 557-572.

Cuc LM, Huyen LTN, Hien PTM, Hang VTT, Dam NQ, Mui PT, Quang VD, Ismail AM and Ham LH (2012) Application of marker assisted backcrossing to introgress the submergence tolerance QTL SUB1 into the Vietnam elite rice variety-AS996. American Journal of Plant Sciences 3: 528-536.

Davey JW, Hohenlohe PA, Etter PD, Boone JQ, Catchen JM and Blaxter 
ML (2011) Genome-wide genetic marker discovery and genotyping using next-generation sequencing. Nature 12: 499-510.

Delannay X, McLaren G and Ribaut J-M (2012) Fostering molecular breeding in developing countries. Molecular Breeding 29: 857-873.

Fritsche-Neto R, Vale JC, Lanes ÉCM, Resende MDV and Miranda GV (2012) Genome-wide selection for tropical maize root traits under conditions of nitrogen and phosphorus stress. Acta Scientiarum. Agronomy 34: 389-395.

Fu-Hao L, Soon-Wook K, Min-Young Y, Ki-Taek K, Myeong-Cheoul C, Moo-Kyung Y and Yong-Jin P (2012) SNP marker integration and QTL analysis of 12 agronomic and morphological traits in $\mathrm{F}_{8}$ RILs of pepper (Capsicum annum L.). Molecules and Cells 34: 25-34.

Garcia C, Lima B, Almeida A, Marques W, Resende M, Vencovsky R and Grattapaglia D (2011) Genome-wide selection for Eucalyptus improvement at international paper in Brazil. BMC Proceedings 5: p. 44 (Supp1 7).

Grattapaglia D and Resende MDV (2011) Genomic selection in forest tree breeding. Tree Genetics and Genomes 7: 241-255.

Gupta PK, Langridge P and Mir RR (2010) Marker-assisted wheat breeding: present status and future possibilities. Molecular Breeding 26: $145-161$.

Hospital F (2009) Challenges for effective marker-assisted selection in plants. Genetica 136: 303-310.

Iftekharuddaula KM, Newaz MA, Salam MA, Ahmed HU, Mahbub MAA, Septiningsih EM, Collard BCY, Sanchez DL, Pamplona AM and Mackill DJ (2011) Rapid and high-precision marker assisted backcrossing to introgress the SUB1 QTL into BR11, the rainfed lowland rice mega variety of Bangladesh. Euphytica 178: 83-97.

Liu YB, Wei W, Ma KP and Darmency H (2010) Backcrosses to Brassica napus of hybrids between $B$. juncea and B. napus as a source of herbicide-resistant volunteer-like feral populations. Plant Science 179: 459-465.

Ma JQ, Zhou YH, Ma CL, Yao MZ, Jin JQ, Wang XC and Chen L (2010) Identification and characterization of 74 novel polymorphic EST-SSR markers in the tea plant, Camellia sinensis (Theaceae). American Journal of Botany: e153-e156.

McCouch SR, Zhao K, Wright M, Tung C-W, Ebana K, Thomson M, Reynolds A, Wang D, DeClerck G, Ali Md. L, McClung A, Eizenga $\mathrm{G}$ and Cs (2010) Development of genome-wide SNP assays for rice. Breeding Science 60: 524-535.

Micallef MC, Austin S and Bingham ET (1995) Improvement of transgenic alfalfa by backcrossing. In Vitro Cellular \& Developmental Biology 31: 187-192.

Miklas PN (2007) Marker-assisted backcrossing QTL for partial resistance to sclerotinia white mold in dry bean. Crop Science 47: 935-942.

Mishra RK, Gangadhar BH, Nookaraju A, Kumar S and Park SW (2012) Development of EST-derived SSR markers in pea (Pisum sativum) and their potential utility for genetic mapping and transferability.

\section{Plant Breeding 131: 118-124.}

Moose SP and Mumm RH (2008) Molecular plant breeding as the foundation for 21st century crop improvement. Plant Physiology 147: 969-977.

Mulato BM, Möller M, Zucchi MI, Quecini V and Pinheiro JB (2010) Genetic diversity in soybean germplasm identified by SSR and EST-SSR markers. Pesquisa Agropecuária Brasileira 45: 276-283.

Oliveira EJ, Resende MDV, Santos VS, Ferreir CF, Oliveira GAF, Silva MS, Oliveira LA and Aguilar-Vildoso CI (2012) Genome-wide selection in cassava. Euphytica 187: 263-276.

Paterson AH, Lander ES, Hewitt JD, Peterson S, Lincoln SE and Tanksley SD (1988) Resolution of quantitative traits into Mendelian factors by using a complete linkage map of restriction fragment length polymorphisms. Nature 335: 721-726.

Ribaut JM, Vicente MC and Delannay X (2010) Molecular breeding in developing countries: challenges and perspectives. Current Opinion in plant Biology 13: 1-6.

Roy S, Banerjee A, Tarafdar J, Senapati BK and Dasgupta I (2011) Transfer of transgenes for resistance to rice tungro disease into high-yielding rice cultivars through genebased marker-assisted selection. Journal of Agricultural Science 150: 610-618.

Roy S, Banerjee A, Tarafdar J and Senapati BK (2012) Detection of probable marker-free transgene-positive rice plants resistant to rice tungro disease from backcross progenies of transgenic Pusa Basmati 1. Journal of Genetics 91: 213-218.

Ruane J and Sonnino A (2007) Marker-assisted selection as a tool for genetic improvement of crops, livestock, forestry and fish in developing countries: an overview of the issues. In Guimaraes EP, Ruane J, Scherf BD, Sonnino A and Dargie JD (eds.) Markerassisted selection: current status and future perspectives in crops, livestock, forestry and fish. FAO, Agriculture and Consumer Protection Dept., Rome. p. 3-13.

Schuster I (2011) Marker-assisted selection for quantitative traits. Crop Breeding and Applied Biotechnology S1: 50-55.

Shirasawa K, Isobe S, Hirakawa H, Asamizu E, Fukuoka H, Just D, Rothan H, Sasamoto S, Fujishiro T, Kishida Y, Kohara M, Tsuruoka H, Wada T, Nakamura Y, Sato S and Tabata S (2010) SNP discovery and linkage map construction in cultivated tomato. DNA Research 17: 381-391.

Siangliw JL, Jongdee B, Pantuwan G and Toojinda T (2007) Developing KDML105 backcross introgression lines using marker-assisted selection for QTLs associated with drought tolerance in rice. ScienceAsia 33: 207-214.

Yamini KN, Ramesh K, Naresh V, Rajendrakumar P, Anjani K and Kumar VD (2013) Development of EST-SSR markers and their utility in revealing cryptic diversity in safflower (Carthamus tinctorius L.). Journal of Plant Biochemistry and Biotechnology 22: 90-102.

Ye C, Argayoso MA, Redoña ED, Sierra SN, Laza MA, Dilla CJ, Mo Y, Thomson MJ, Chin J, Delaviña CB, Diaz GQ and Hernandez JE (2012) 
NS Sakiyama et al.

Mapping QTL for heat tolerance at flowering stage in rice using SNP markers. Molecular Breeding 131: 33-41.

Xu Y and Crouch JH (2008) Marker-assisted selection in plant breeding: from publication to practice. Crop Science 48: 391-407.
Zou Z, Ishida M, Li F, Kakizaki T, Suzuki S, Kitashiba H and Nishio T (2013) QTL analysis using SNP markers developed by nextgeneration sequencing for identification of candidate genes controlling 4-methylthio-3-butenyl glucosinolate contents in roots of radish, Raphanus sativus L. PLoS ONE 8: e53541. 